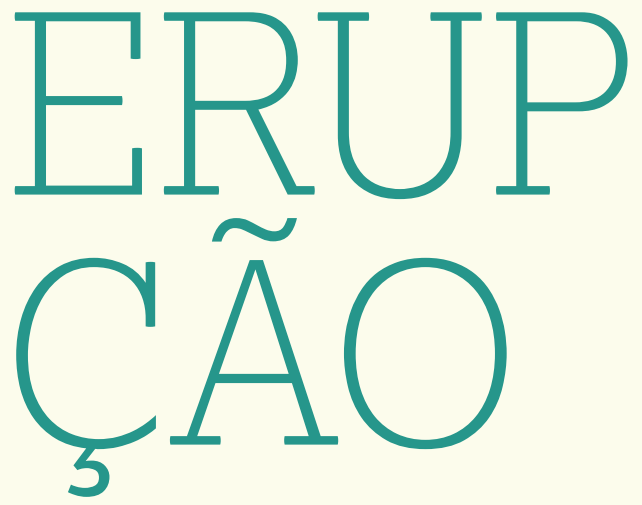

Do latim eruptio, -onis. Saída impetuosa. Explosão, jacto de matérias.

Evento vulcânico. 



\section{AUTOBIOGRAFIAS DO COMEÇO DE UMA AULA ${ }^{1}$ \\ - MARCOS NATALI}

[1] Parte deste texto é uma versão revisada de dois blocos do Memorial Acadêmico submetido em junho de 2016 ao Departamento de Teoria Literária e Literatura Comparada da Universidade de São Paulo, como parte do concurso para Livre-Docência. Outra parte, identificada abaixo em nota, foi apresentada em aula da disciplina "Questões de literatura e ética", ministrada na USP no primeiro semestre de 2016.
$\mathrm{P}$ aletó puído, cabelos brancos desgrenhados, ele entra na sala de aula e começa a escrever na lousa. Assim que ele cruza a porta, centrando-se em seus movimentos sem se desviar. Após alguns minutos, com a lousa já parcialmente preenchida, a câmera gira, revelando que todas as carteiras da sala na verdade estão vazias. Enquanto isso, permanece audível, ao fundo, os ruídos do pontilhar do giz, junto à voz de Nicanor Parra, que continua com sua aula.

É nessa cena e em Nicanor Parra que ela pensa enquanto atravessa caminhando o longo corredor do prédio. Ela sabe que, terminado o corredor, terá ainda que cruzar a arena povoada de carteiras, mochilas, cadernos - e vozes - para chegar à mesa vazia, que ela então começará a cobrir de livros, folhas, pastas, cada um deles um amuleto pronto para ajudá-la a encarar os habitantes desse estranho território, essas bocas que, aos poucos, talvez em parte graças ao efeito dos amuletos, começam a se transformar em olhos e ouvidos. Mas antes que isso aconteça há sempre alguns momentos, cuja duração é impossível prever, que talvez ainda possam ser estendidos mais um pouco, até chegar o instante em que ela não terá outra opção a não ser começar a falar.

Se chegou até ali, diante daqueles olhos, se agora se encontra entre eles e a lousa, e se olhos e lousa parecem esperar algo dela, já não haverá como escapar à fala. É para isso que vieram, ela pensa; e no entanto, estranhamente, também eles parecem desejar adiar o começo, com conversas entre si cuja velocidade aumenta à medida que diminui o seu volume. (Só muito tempo depois lhe ocorrerá que pode ser para isso, na verdade, 
que eles vêm: para essa conversa com os colegas - e que na verdade é a fala dela que é a interrupção.)

Prestes a falar, ainda a desnorteia pensar que seu prazer por estar ali, sentada entre pares, de frente para a lousa, escutando e escrevendo, tenha sido responsável por conduzi-la ao lugar que agora ocupa, diante (distante) deles. Claro, vaidade, narcisismo, egocentrismo, o gosto por escutar a própria voz: nada disso lhe é estranho, propriamente. Mas - ela se lembra - sua fascinação pela sala de aula surgiu de uma experiência diferente dessa pela qual passa agora; surgiu do entusiasmo de estar sentada, em silêncio, com direito ao silêncio, acompanhando o teatro do pensamento (que era na verdade mais de um: o que ocorria diante dela e o que se desenrolava secretamente dentro dela, em resposta). Um exercício de escuta, portanto, aparentemente o avesso da situação atual, na qual para ela o silêncio parece estar proibido, enquanto a possibilidade de escutar o outro é rara e difícil, exigindo um empenho colossal para se chegar ao ponto em que o aluno ou a aluna deseje, enfim, talvez, falar. "How gladly", ela recita em silêncio, "how gladly would I come down from this mast-head and sit on the hatches there where you sit, and listen as you listen, while some one of you reads me that other and more awful lesson which Jonah teaches to me". ${ }^{2}$ Mas esse barco já partiu, já não há onde se esconder, nesse ambiente sem colunas ou sombras, e será assim durante noventa minutos (e duas vezes por semana ao longo de quatro meses!).

[2] MelviLle, H. Moby-Dick, or the Whale. Evanston: Northwestern University Press, 1991, p.47.

Quando finalmente começa a falar, sua voz se mescla às vozes que compõem as diferentes conversas simultâneas, os últimos sussurros resistindo ainda mais um pouco à interrupção inoportuna: Sempre que me encontro falando diante de muita gente sinto que errei de porta (essas suas primeiras palavras repetem as que um dia disse García Lorca em Nova York, no início de um evento público em que leria seus poemas) e é como se umas mãos amigas tivessem me empurrado, bem de leve continuou García Lorca naquele dia, continua ela agora - e, de repente, um pouco assustada, me vejo mais uma vez diante de uma sala repleta de pessoas sentadas. Algumas pessoas saem a caminhar pela cidade e se deparam com as coisas mais bizarras - um jacaré prestes a devorá-las, por exemplo; já comigo, em vez disso, o que costuma acontecer é eu me encontrar diante de um público, diante de pessoas que parecem estar à espera de que eu fale.

Assim, o que terei que fazer hoje com vocês - suspira García Lorca - é lutar; lutar contra um dragão enorme (vejam só, ela diz: o animal já cresceu, já 
não é um simples jacaré!), um dragão que neste exato momento se encontra diante de mim (sinto sua respiração quente e ansiosa). E eu sei - ela lembra que ele disse -, eu sei que esse dragão pode a qualquer momento me devorar, e me devorar (adivinhem o que ele diz!) com seus bocejos.

Ah, diz García Lorca, mas a história não acabou, pois eu tenho como me proteger desse dragão feroz; eu tenho uma capa poderosa que nunca falha, e a ela apelo quando estou diante dessas 300 cabeças serpentinas (para mim são 60, ela diz), essas cabeças que como numa coreografia parecem bocejar todas ao mesmo tempo. Diante do coro de bocejos, mas também diante da mão que logo se levanta cobrando explicações, minha capa diz: "A culpa é sua!" Eu sei, eu sei: a saída é um pouco agressiva, e é provável que a acusação feita pela capa seja infundada. Mas é o que tenho ao meu alcance, e é como imagino poder responder à exigência de que me explique, mais uma vez, eu que nunca soube explicar nada, eu que apenas sei balbuciar o fogo que me queima.

No dia em que resolveu começar a aula com essa anedota emprestada de García Lorca, invocando o espectro de García Lorca numa cidade estrangeira, ela o fez não exatamente por compartilhar sua hostilidade aos pedidos de explicação (para ela a mão que é erguida na sala é sempre uma boia de salva-vidas lançada em sua direção). Também não a incomodam os bocejos na sala de aula, nem as cabeças que repousam sobre as mesas no meio da aula.

(Ou já não a incomodam mais, ou pelo menos não da mesma forma que antes: no sono dos alunos na sala de aula o que ela enxerga hoje é também a história da cidade de São Paulo, com suas avenidas e túneis, sua indústria do transporte particular. E enxerga o tempo do deslocamento entre as margens da cidade e aquilo que se conhece como a "Cidade Universitária”, essa cidade dentro de outra, com guaritas, portões e muros entre uma e outra. No bocejo da aluna está a escassez de linhas de metrô, estão os desvios de verbas na construção de um metrô que cobre pouco a cidade, está a definição da preferência pelo carro. Naquela aula, para alunos do primeiro semestre do primeiro ano, alguns pareciam sobreviventes dessa travessia, todos os dias cruzando a cidade por uma, duas, três horas, até chegarem à sala de aula, refúgio onde poderão, enfim, dormir. Ela fala baixo para não acordá-los.)

No sono há também a sinalização da existência de um limite. Se com o começo da aula as conversas paralelas em sala deixam de ser viáveis (as 
vozes atrapalham a escuta e a concentração dos demais), o aluno que dorme pode ser visto como participante num ato de recusa - ao tédio da aula, quem sabe, ou então à sua irrelevância, ao menos para ele, ao menos naquele momento. Nem toda aula é para todos, diz Deleuze, nem tudo na aula vai servir do mesmo modo para cada um dos que estão ali, e o aluno que sonha - acordado ou dormindo - poderá voltar, se em algum momento julgar que aquilo que está sendo dito voltou a lhe servir de alguma maneira. Para ela essa formulação de Deleuze surgiu um alívio; permitiu que ela pensasse a aula - e a escrita, a literatura, a fala - como uma operação que não precisa ser para todos. A observação aparecia como a verbalização de um modo de estar com outros que não exige a homogeneidade, a possibilidade de uma concepção menos autoritária de democracia, uma na qual a recusa, o silêncio e o segredo seriam significativos e legítimos e teriam um lugar. (É difícil, afinal, resguardar a afirmação de que todos podem da exigência de que todos, portanto, devem.) E é por isso que são fundamentais na sala de aula o atrito, o dissenso, um limite para o ensino como transmissão do conhecido, um limite para uma democracia apenas pedagógica.

(A aula não é sinônimo de mercado, embora os dois se cruzem; mas o sono parece ser um limite também para a economia contemporânea, com sua fantasia de um funcionamento ininterrupto da produção e do consumo. Apesar dos danos ao sono já causados pelo capitalismo acelerado, e enquanto continuam os experimentos em busca de uma forma de vida que prescinda do sono, pode-se enxergar alguma esperança na necessidade de descanso que corpos e mentes insistem em ter: "é fonte de otimismo o fato de que há um intervalo crucial do tempo humano que é de fato impossível de ser conquistado pelas forças da mercantilização", escreve Jonathan Crary. ${ }^{3}$ )

O crítico argentino Daniel Link, que também em algum momento citou o episódio de García Lorca em Nova York, relata como apostando em um público (ouvinte? leitor?) que compartilhe sua paixão: se "para os demais serei $a$ ou $b$ ou... $n$ ", para "quem participa do mesmo amor que eu (o amor a um certo 'nós'), serei $a+b \ldots .+n$." Esse é o "espetáculo total do que eu sou" e que nem eu imagino que sou "(o amor nasce e se alimenta dessa interpretação silenciosa)". ${ }^{4}$ Dirigindo-se novamente à sala, ela conta que nessa formulação de Link escuta algo como o seguinte: não sou necessariamente a melhor intérprete dessa personagem que sou, e aquilo que se conhece como minha "biografia" não estaria mais disponível para mim do março de 2012.

[3] CRARY, J. 24/7: capitalismo tardio e os fins do sono. Tradução de J. Toledo. São Paulo: Cosac Naify, 2014. 
[5] Foucault, M. A Coragem da Verdade. O governo de si e dos outros II. Curso dado no Collège de France. (1983-1984). Tradução de E. Brandão. São Paulo: Martins Fontes, 2011.

[6] Derrida, J. e Ferraris, M. El gusto del secreto. Tradução de L. Padilla López. Buenos Aires: Amorrortu, 2009, p.45-6. É em um lugar próximo dessa intuição que Jean-Luc Nancy vai terminar em sua leitura do difícil trecho do Evangelho segundo Mateus que afirma, estranhamente, que "Àquele que tem Ihe será dado, e estará na abundância, mas àquele que não tem, mesmo o que tem Ihe será tirado." A possibilidade de um ouvinte ser tocado por uma fala dependerá de sua experiência prévia, formadora de sua disposição receptiva, pois há elementos na recepção que são condições para o acontecimento: "Eis por que Ihes falo em parábolas: porque eles olham sem ver e ouvem sem ouvir. Para eles se cumpre a profecia: Por muito que ouçais, não compreendereis; por muito que olheis, não vereis." Em Nancy, J-L. Noli me tangere: Essai sur la levée du corps/Marie, Madeleine. Paris: Bayard, 2003. a um outro, que posso vir a ser. O sujeito não é nem a origem nem o princípio organizador do pensamento e da escrita.

Como na cena de García Lorca diante dos dragões, ela diz, o signo “+” nos coloca de novo em tensão com certa noção de explicação. Naquele dia em Nova York, García Lorca ia ler poemas, o que não é insignificante, mas essa diferença não é suficiente para estabelecer uma alteridade absoluta em relação àquilo que se faz numa sala de aula. Seja como for, o sonho de uma palavra irredutível ao discurso da explicação é algo que às vezes recebe justamente o nome de literatura (entre outros possíveis e não menos legítimos), o que faz com que a sala de aula que se debruça sobre textos conhecidos como literários contenha um potencial próprio para a complicação da noção de explicação. Nesta sala de aula, o que acontecerá não estará exatamente alheio à esfera da explicação, mas haverá nela, ao mesmo tempo, um uso da linguagem que precisaria ser chamado por outro nome.

Durante o curso "A coragem da verdade", ministrado por Foucault em 1983, o nome parresía aparece como proposta para um "modelo de crítica". ${ }^{5}$ Nesse "dizer verdadeiro", postura dos cínicos antigos que tanto intrigou a Foucault, haveria uma abertura para a filosofia como "prática de vida", uma prática por sua vez caracterizada "pela insolência e pelo escândalo" que talvez ainda pudesse ser considerada "pedagógica", mas na qual o corpo desempenharia um papel decisivo. Se a verdade de qualquer dizer está associada à relação entre aquela que fala e aquilo que ela diz, o sentido estaria não apenas no "conteúdo" da fala, mas na relação entre ele e o modo do dizer, incluindo o corpo, seus movimentos e gestos, as modalidades do olhar, as modulações da voz. Em outras palavras, ela diz, não é indiferente que quem esteja dizendo tudo isto hoje seja eu, e que o faça neste momento como professora. Certa vez, ao ser questionado sobre a ininteligibilidade de sua fala, após uma palestra particularmente hermética, Deleuze disse: mas há tantas formas de tocar o receptor, há tantas coisas que ele pode estar assimilando a qualquer momento e que não se limitam ao inteligível! Também em uma entrevista (esse gênero comumente entendido justamente como a oportunidade para o esclarecimento - daquilo que se escreveu, por exemplo), Derrida dirá: mas não está nada claro que o que queremos é sempre ser legíveis, que desejamos que aquilo que escrevemos seja legível para todos, e não apenas para alguns. ${ }^{6}$ Talvez não para todos, então, ou não necessariamente, ou não do mesmo modo para cada um, mas definitivamente para outros, para um ou vários, para um outro desconhecido, estrangeiro e 
inesperado, sempre mais do que o mesmo, mais do que eu, potencialmente coletivo, logo necessariamente político, nessa busca não de uma transmissão ou comunicação, mas da criação de algo a partir de nada, o exercício de trazer o inexistente à existência. Para Badiou, seria essa a definição mesma de política, com um detalhe que faz toda a diferença: através de um sujeito coletivo. ${ }^{7}$ Sem a possibilidade da participação criativa das alunas e dos alunos, de modo que a produção na sala de aula seja um ato pelo qual um conjunto de pessoas se faz responsável, não poderá haver política.

Como estamos aqui falando de sono e de sonhos (ela continua, como se estivesse improvisando, como se não fosse premeditada a passagem de um ponto a outro), e se alguns de nós estamos inclusive neste exato momento praticando o sono (mas será possível conjugar o verbo sonhar em primeira pessoa?), vou contar a vocês um sonho de Derrida, um sonho que pode nos aproximar desde outro ângulo à ideia de um estar junto sem a obrigação de ser o mesmo, outra versão da política (e da aula) como a criação de algo que não existia (neste caso, um nós). Ao receber o Prêmio Adorno, e em agradecimento, Derrida diz, naquilo que ficará conhecido como seu "Discurso de Frankfurt":

Há décadas ouço vozes em sonho, como se diz. Às vezes, são vozes amigas, às vezes não. São vozes em mim. Todas parecem dizer-me: por que não reconhecer, clara e publicamente, de uma vez por todas, as afinidades entre seu trabalho e o de Adorno, na verdade, sua dívida para com Adorno? Não é você um herdeiro da Escola de Frankfurt? Em mim e fora de mim, a resposta, com certeza, será sempre complicada, em parte virtual. Mas, a partir deste momento - e também por isso lhes digo "obrigado" - não posso mais fazer de conta que não ouço essas vozes. Se a paisagem das influências, das filiações ou das heranças, das resistências também, continuará sempre atormentada, labiríntica ou abissal, e nesse caso talvez mais contraditória e sobredeterminada do que nunca, hoje, graças a vocês, estou feliz hoje por poder e por dever dizer "sim" à minha dívida para com Adorno, e por várias razões, mesmo se ainda não sou capaz de responder a ela e de responder por ela. ${ }^{8}$

Para começar, haveria que se reconhecer a relevância de tudo isso ter que ser relatado como sendo parte de um sonho. Embora temperada pela ressalva do "como se diz", que enfraquece a literalidade da referência, é a ideia do sonho que permite a aparição das vozes, amistosas ou
[7] Badiou, A. A hipótese comunista. Tradução de M. Echalar. São Paulo: Boitempo, 2012. O número - de "corpos libertos", por exemplo - é decisivo também em "A hipótese anarquista", "provocação" de Moysés Pinto Neto a Badiou. (Em Sopro, n.96, setembro de 2013. http://culturaebarbarie. org/sopro/ index.html.)

[8] Derrida, J. "Discurso de Frankfurt", Le Monde Diplomatique, edição brasileira, ano 3, n. 24 , jan. 2002. 
[9] DerRIDA, J. Espectros de Marx: o Estado da dívida, o trabaIho do luto e a nova Internacional. Tradução de A. Skinner. São Paulo: Relume Dumará, 1994, p.33.
[10] O que segue, desta até a página 33, é uma versão do texto apresentado, como "despedida à aula expositiva”, na primeira aula da disciplina "Questões de literatura e ética”.

[11] Agostinho, Confissões. Tradução de M. L. Jardim Amarante. São Paulo: Paulus, 1984

[12] O debate, que aconteceu no dia 9 de novembro de 2002 em Toronto como parte do encontro anual da American Academy of Religion e da Society of Biblical Literature, não foi transcrito ou recolhido em livro, até onde sei. O áudio do debate está disponível em https://www.sbl-site.org/ publications/ article.aspx?Articleld=332. não, ao mesmo tempo alheias e próprias, externas e internas, a trazer a sugestão de que as heranças são sempre plurais: há sempre mais de um herdeiro, e cada um deles receberá sempre mais de uma herança. A "herança não é jamais una consigo mesma", dirá também Derrida, desta vez nos Espectros de Marx. ${ }^{9}$ Afinal, "Herda-se sempre um segredo - que diz 'leia-me, será que algum dia você será capaz de me ler?'” Pois é preciso filtrar e peneirar a herança, cuja legibilidade não é dada ou natural, nem transparente ou unívoca. Após uma pausa, ela diz que a aula não é apenas sobre isso; a aula é isso -

quando de repente, no meio da aula, no meio da frase, ela começa a escutar a própria voz, como se ela pertencesse a outra, como se a voz viesse de outra. Distantes, por momentos quase inaudiveis, as frases, entrecortadas e incompletas, flutuam pela sala: "...você escreve para descobrir o que escreveria se você escrevesse...” / “...não se trata da superação, mas da suspensão da referencialidade..." - diz essa outra que ela agora observa com curiosidade, com certa apreensão, com compaixão. E ela vê a mulher na frente da sala, caminhando lentamente de um lado a outro, continuando a falar. Percebe que seu olhar se desvia para a janela, onde nota o passarinho amarelo sentado no parapeito. O que ele fará com esta aula?, escuta que a outra pergunta.

Como seria dar aula para Deus $?^{10}$

O estranhamento provocado pela pergunta parece vir da inserção, na relação pedagógica, da figura de Deus. Deus, se for alguma coisa, não seria justamente o ser que não careceria de ensino, aquele a quem não haveria qualquer lição a dar? Como ensinar quem já sabe, alguém que certamente sabe mais do que eu?

É antiga a questão do endereçamento a Deus e a pergunta sobre o estatuto específico do discurso que é dirigido a Deus (a oração, a súplica, a confissão). E é uma versão dessa pergunta que Santo Agostinho volta a formular em suas Confissões: por que motivo eu confessaria a alguém que já conhece - que conhece melhor do que eu, que sabe antes do que eu - o que tenho a dizer? ${ }^{11}$

Numa mesa redonda realizada no Canadá em 2002, ${ }^{12}$ diante de um público de teólogos e estudiosos de religião, o filósofo John Caputo aborda a mesma questão, desta vez voltando a um trecho da Circonfissão de Derrida 
(texto que é, entre outras coisas, uma leitura de Santo Agostinho). ${ }^{13}$ No início do debate, já na primeira pergunta que dirige a Derrida, Caputo cita um trecho da Circonfissão em que Derrida escrevera que, caso conhecessem as circunstâncias de seu modo de rezar, se soubessem não só como, mas sobretudo para quem ele rezava, saberiam tudo. O que Caputo deseja saber não é outra coisa: afinal, para quem você reza?

A resposta de Derrida é cheia de voltas e desvios, mas começa com a manifestação de seu desconcerto: Vejam só, ele quer saber tudo de mim! E me pergunta isso... em público. Em público! Nos rodeios da resposta, tentando manter secreto aquilo que não desejava expor, Derrida apela a matizações e condições - quando rezo, se é que eu rezo...; nas minhas orações, ser for mesmo verdade que eu rezo... - para então afirmar que para ele a prática da oração sempre esteve associada ao segredo. Mesmo quando em público, como em sua infância na Argélia, mesmo quando junto a outros - numa sinagoga, por exemplo - rezar foi sempre algo que interrompia a comunidade. Rezar seria, em outras palavras, uma possibilidade de estar com outros sem precisar ser igual a eles, sem precisar se fundir a eles. E seria também, numa definição pouco comum, o modo do discurso em que seria possível fazer todas as perguntas.

Por outro lado, no estranhamento gerado pela pergunta sobre uma hipotética aula para Deus, o que se revela é também algo relevante sobre nossa compreensão do outro termo importante da frase: o ensino. Desponta, em particular, a ligação forte entre ensino e explicação, todos os instantes em que o ensino é entendido apenas como a transmissão de conhecimento já possuído (pelo mestre). É a lógica da explicação e o papel do explicador na sala de aula o que chama a atenção também de Jacques Rancière, em sua longa reflexão sobre o caso do pedagogo Joseph Jacotot:

A lógica da explicação comporta, assim, o princípio de uma regressão ao infinito: a reduplicação das razões não tem jamais razão de se deter. O que detém a regressão e concede ao sistema seu fundamento é, simplesmente, que o explicador é o único juiz do ponto em que a explicação está, ela própria, explicada. Ele é o único juiz dessa questão, em si mesma vertiginosa: teria o aluno compreendido os raciocínios que lhe ensinam a compreender os raciocínios? (...) Esse status privilegiado da palavra não suprime a regressão ao infinito, senão para instituir uma hierarquia paradoxal. Na ordem do explicador, com efeito, é preciso uma explicação oral para explicar a explicação escrita. Isso supõe que os raciocínios são mais claros —imprimem-se melhor no
[13] DerRIDA, J. "Circonfissão". In: G. Bennington e J. Derrida, Jacques Derrida. Tradução de A. Skinner. Rio de Janeiro: Jorge Zahar, 1996. Para um estudo mais detido da questão do destinatário na oração, e também desse texto de Derrida, ver o ensaio "O sacrifício da literatura" (publicado primeiro em Alea: Estudos Neolatinos, v. 15, p. 201-217, 2013, e depois em Marcos Siscar e Marcos NatalI [orgs.]. Margens da democracia: a literatura e a questão da diferença. Campinas/São Paulo: Ed. da Unicamp/Edusp, 2015, p.269-302).

[14] RANCIĖRE, J. O mestre ignorante: cinco lições sobre a emancipação intelectual. Tradução de L. do Valle. Belo Horizonte: Autêntica, 2007, p.21-22. 
[15] IDEM, p.23-24.

[16] LINK, D. "Leer: experimentar". In: C. Bartalini e G. Zarza, eds. América Latina como problema: literatura - cultura - educación. Buenos Aires: Universidad Nacional Arturo Jauretche, 2016, p.143. espírito do aluno - quando veiculados pela palavra do mestre, que se dissipa no instante, do que no livro, onde estão inscritas para sempre em caracteres indeléveis. Como entender esse privilégio paradoxal da palavra sobre a escrita, do ouvido sobre a vista? ${ }^{14}$

Rancière concluirá que os motivos para a instituição dessa hierarquia entre oralidade e escrita e para a concessão de privilégios à ordem da explicação terão que ser buscados em outro lugar:

A explicação não é necessária para socorrer uma incapacidade de compreender. É, ao contrário, essa incapacidade, a ficção estruturante da concepção explicadora de mundo. É o explicador que tem necessidade do incapaz, e não o contrário, é ele que constitui o incapaz como tal. Explicar alguma coisa a alguém é, antes de mais nada, demonstrar-lhe que não pode compreendê-la por si só. Antes de ser o ato do pedagogo, a explicação é o mito da pedagogia, a parábola de um mundo dividido em espíritos sábios e espíritos ignorantes, espíritos maduros e imaturos, capazes e incapazes, inteligentes e bobos. O procedimento próprio do explicador consiste nesse duplo gesto inaugural: por um lado, ele decreta o começo absoluto - somente agora tem início o ato de aprender; por outro lado, ele cobre todas as coisas a serem aprendidas desse véu de ignorância que ele próprio se encarrega de retirar. ${ }^{15}$

O curto circuito provocado nesse mito da pedagogia seria o problema com a especulação a respeito de uma aula em que Deus é o aluno, inclusive pela impossibilidade de afirmar que com a aula finalmente começaria seu aprendizado. Esse é o potencial escondido na pergunta. Como teria que ser adaptada a forma de uma aula que não pudesse pressupor a ignorância dos alunos, uma aula que não se submetesse inteiramente à lógica da explicação? Como seria uma aula que colocasse em questão a assimetria e o progressivismo que são as premissas da relação pedagógica? (Tentando demonstrar que a alternativa não precisaria ser algo que pudesse ser chamado de "relativismo", Daniel Link cita Barthes, para sonhar com o tremor da diferença e com um pluralismo nietzschiano que não se afundasse na multiplicidade do liberalismo. ${ }^{16}$ ) A questão é ao mesmo tempo radicalmente local - diz respeito às peculiaridades desse espaço particular que é a sala de aula - e condensa todo o funcionamento das sociedades modernas (que Rancière chamará de "sociedades pedagógicas”).

Quanto a Santo Agostinho, sua resposta à pergunta que dirige a si mesmo (e ao outro em si) - por que confessar a Deus, se é mais fácil 
esconder algo de mim mesmo do que dele? - é a seguinte: o objetivo desse tipo de discurso é fazer ou criar a verdade. Não, portanto, revelar ou corresponder a ela, mas gerá-la. O modelo para essa fala - para a confissão, para a aula - não seria então a comunicação de duplo-clique de que fala Bruno Latour, ${ }^{17}$ mas o artesanato. Entre o monólogo e o diálogo, com a esperança da passagem da fala solitária à construção conjunta, o desafio é ter ao mesmo tempo o máximo de rigor e disciplina e o máximo de liberdade. Como com qualquer exercício de improvisação, a necessidade de preparação aumenta, em vez de diminuir; mesmo que a aula signifique "momentos de inspiração, senão não quer dizer nada", como propõe Deleuze, é verdade também que "se não tivermos ensaiado o bastante, não estaremos inspirados" ${ }^{18}$ "Improvisar", em outras palavras, seria

o exercício da virtude primeira de nossa inteligência: a virtude poética. A impossibilidade que é a nossa de dizer a verdade, mesmo quando a sentimos, nos faz falar como poetas. Narrar as aventuras de nosso espírito e verificar se são compreendidas por outros aventureiros, comunicar nosso sentimento e vê-lo partilhado por outros seres sencientes. (...) No ato de palavra, o homem não transmite seu saber, ele poetiza, traduz e convida os outros a fazer a mesma coisa. Ele se comunica como artesão: alguém que maneja as palavras como instrumentos. (...) Ele se comunica como poeta: um ser que crê que seu pensamento é comunicável, sua emoção, partilhável. Por isso, o exercício da palavra e a concepção de qualquer obra como discurso são um prelúdio para toda aprendizagem. ${ }^{19}$

Nesses termos, a sensação constante seria a de que a aula pode não dar certo, que ela pode fracassar, pois nessa emoção antes do começo da aula está a percepção da iminência de um acontecimento, imprevisto e imprevisível, impossível de anular com a preparação, as anotações, os roteiros, as leituras prévias, inclusive porque ele depende dos outros. Essas aulas estariam sempre à beira do desconhecimento e seriam sempre sobre aquilo que ainda não se sabe. Mais difícil do que o congresso acadêmico, mais desafiador do que a leitura de uma conferência, não haveria receita disponível de antemão; o dilema da sala de aula não teria como ser resolvido senão na prática, na tensão entre a leitura solitária dos textos, por um lado, e a conversa na sala de aula. Sua forma seria um experimento em busca de modos de responder aos textos, aos acontecimentos e aos outros, fazendo da aula a aventura do que pode ser pensar ao lado de outras pessoas.
[17] Em contraste com os discursos amoroso e religioso, escreve Latour, a "comunicação de duplo-clique quer que acreditemos que é factível transportar, sem a menor deformação, uma informação precisa qualquer sobre situações e coisas que não estão presentes aqui. Nos casos mais ordinários, quando as pessoas perguntam 'isso é verdade?', 'isso corresponde a alguma situação de fato?', o que têm em mente é uma espécie de ato ou comando como o duplo-clique, que permita acesso imediato à informação; e é nisso que se dão mal, porque é assim também que se falseiam os modos de falar que nos são mais caros. O discurso religioso, ao contrário, busca justamente frustrar a tendência ao duplo-clique, desviá-la, rompê-la, subvertê-la, torná-la impossível. A fala religiosa, como a fala amorosa, quer garantir que até mesmo os mais alheados, os mais distantes observadores voltem a estar atentos, para que não percam seu tempo a ignorar o chamado à conversão. (...) Transporte de informação sem deformação não é, não é de modo algum uma das condições de felicidade do discurso religioso." Em Latour, B. “'Não congelarás a imagem', ou: como não desentender o debate ciência-religião". MANA, 10(2), 2004, p.355.

[18] Deleuze, G. O abecedário. Entrevista a Claire PARNET (1988). Transcrição e tradução do vídeo de T. Tadeu da Silva. Disponível em http://escolanomade.org/ wp-content/downloads/deleuze-o-abecedario.pdf.

[19] Rancière, J. O mestre ignorante, op. cit., p.96-7. 
[20] Barthes, R. A preparação do romance. Tradução de L. Perrone-Moisés. São Paulo: Martins Fontes, 2005
[21] “É necessário chegar ao ponto de falar de algo com entusiasmo. O ensaio é isso. Eu precisava menos disso. $\mathrm{E}$ as aulas são algo muito especial. Uma aula é um cubo, ou seja, um espaço-tempo. Muitas coisas acontecem numa aula. Nunca gostei de conferências porque se trata de um espaço-tempo pequeno demais. Uma aula é algo que se estende de uma semana a outra. É um espaço e uma temporalidade muito especiais. Há uma sequência. Não podemos recuperar o que não conseguimos fazer. Mas há um desenvolvimento interior numa aula. $E$ as pessoas mudam entre uma semana e outra. O público de uma aula é algo fascinante." Em Deleuze, G. $O$ abecedário, op. cit.

[22] IDEM.
Nesse sentido, A preparação do romance não seria a ruína precoce do romance que Barthes não chegou a escrever, nem seria a prova de uma empreitada fracassada, que não teria chegado ao seu fim. ${ }^{20}$ Seria, ao contrário, o testemunho do desejo de compartilhar até a escrita e o pensamento solitários. A sala de aula e esse estranho curso sobre a escrita de um romance, imaginado e levado a cabo por Barthes de 1978 a 1980, podem ter sido não um obstáculo à experiência verdadeira (a escrita literária), como o exercício às vezes é lido, mas justamente a coisa mais importante, o esboço de uma vida em comum que ao mesmo tempo guardaria um lugar para a solidão e o silêncio, no tempo entre uma aula e outra. ${ }^{21} \mathrm{O}$ movimento entre a solidão e a assembleia volta nessa formulação curiosa de Deleuze, logo após trecho em que afirma que numa aula "o mais importante é a relação entre a voz e o conceito":

Para mim, duas coisas são importantes: a relação que podemos ter com os estudantes é ensinar que eles fiquem felizes com sua solidão. Eles vivem dizendo: "Um pouco de comunicação. Nós nos sentimos sós, somos todos solitários". Por isso eles querem escolas. Eles não poderão fazer nada em relação à solidão. Temos de ensinar-lhes os benefícios da sua solidão, reconciliá-los com sua solidão. Esse era o meu papel de professor. O segundo aspecto é um pouco a mesma coisa. Não quero lançar noções que façam escola. Quero lançar noções e conceitos que se tornem correntes, que se tornem não exatamente ordinárias, mas que se tornem ideias correntes, que possam ser manejadas de vários modos. Isso só é possível se eu me dirigir a solitários que vão transformar as noções ao seu modo, usá-las de acordo com suas necessidades. Tudo isso são noções de movimento, não de escola. ${ }^{22}$

É uma paradoxal pedagogia da solidão, então, uma solidão compartilhada, um estar junto para ensinar e aprender a estar só, também uma verdade profunda da sala de aula. (E esse trecho de Deleuze - vejam só que coisa - me foi apresentado por uma aluna!)

No caso particular da aula dedicada à literatura, o risco especial é fazer dessa prática discursiva - de sua ideia, de um repertório de obras - garantia e segurança, colocando em perigo o reconhecimento da necessidade de que algo seja feito para transformar o que é compartilhado na sala de aula, colocando em risco esse direito à solidão e ao segredo que é, na verdade, outro nome para a possibilidade do dissenso. Trata-se, ao contrário, de tentar pensar justamente aquilo que é oferecido como garantia e obrigação - para o pensamento, para o afeto, mas 
também para a sobrevivência da instituição (do ensino de literatura). Em outras palavras, importando uma formulação de Adorno adaptada de outro contexto, o que seria preciso identificar e criticar "nessa forma de metafísica é a tentativa de se apropriar, sub-repticiamente, sem teologia, das possibilidades da experiência que foram teologicamente colocadas"23 - ou seja, o risco da literatura como nova religião. Ou então, modificando algumas palavras em um trecho de $A$ ordem do discurso, inserindo referências à literatura e à literafilia onde Foucault escreveu discurso e logofilia:

parece-me que sob esta aparente veneração da [literatura], sob essa aparente [literofilia], esconde-se uma espécie de temor. Tudo se passa como se interdições, supressões, fronteiras e limites tivessem sido dispostos de modo a dominar, ao menos em parte, a grande proliferação da [literatura]. De modo que sua riqueza fosse aliviada de sua parte mais perigosa e que sua desordem fosse organizada segundo figuras que esquivassem o mais incontrolável; tudo se passa como se tivessem querido apagar até as marcas de sua irrupção nos jogos do pensamento e da linguagem. Há, sem dúvida, em nossa sociedade e, imagino, em todas as outras mas segundo um perfil e facetas diferentes, uma profunda [literofobia], uma espécie de temor surdo desses acontecimentos, dessa massa de coisas [literárias], do surgir de todos esses enunciados, de tudo o que possa haver aí de violento, de descontínuo, de combativo, de desordem, também, e de perigoso, desse grande zumbido incessante e desordenado da [literatura].

No interior da instituição, e precisamente na confluência entre institucionalidade e literatura, tudo se passa como se fosse possível delimitar e definir o lugar dessa desordem, impedindo que as intuições surgidas do contato com a literatura contaminem outras esferas (a filosofia, a crítica, a sala de aula, a universidade). É por isso que o caminho - que é o caminho do não ao sim - passa pela sala da aula e pelo reconhecimento da dimensão da questão que a literatura coloca para o ensino.

Ela pensava nisso tudo naquele dia, antes de começar a aula que seria a primeira do semestre, uma aula cujo início ela tinha imaginado assim: "Sim, claro, se amanhã fizer bom tempo". E assim começou a aula, sem referências a trâmites burocráticos - listas de presença, aulas de reposição, horários de atendimento, datas de provas e de entrega 
[24] E a tarefa daqueles que participam de uma aula se torna então saber quando fazer uma pausa, quando se deter: "Quando algo acontece na aula, quando algo pode ser, subitamente, uma verdadeira questão (para todos: estudantes e professor, não só para este último), aí vale a pena demorar, parar, dar um tempo, descrever o impasse e, talvez, perceber que algo está começando a ser vislumbrado, algo que ainda não tinha sido pensado (não por ninguém na tradição filosófica inteira, isso é abstrato, mas por ninguém dos participantes concretos agora e aqui na aula), algo novo e, portanto, que não sabemos ainda como nomear." Em GAGNEBIN, J. M. "O método desviante: Algumas teses impertinentes sobre o que não fazer num curso de filosofia". In: Trópico. Publicado em 3/12/2006. Disponível em http:// www.revistatropico.com.br/tropi$\mathrm{co} / \mathrm{html} /$ textos/2807,1.shl. Acesso em 28/11/2015. de trabalhos: tudo isso ficou para depois, para o final da aula, para um momento menos importante que o começo, buscando tratar com delicadeza o potencial daquele momento inicial. Próximo do teatro, o início da aula é sempre uma fala roteirizada e ensaiada, sempre mais disciplina que desvio, quando a fala está mais próxima do que nunca da folha e da preparação.

A história singular de cada aula será o encontro entre esse programa pensado, antecipado, antevisto, repetido - e o imprevisto. Pois se o começo da aula é o que está escrito, o final não tem como ser programado; não há como saber onde a aula terminará. Máximo de planejamento, máximo de artifício, máximo de rigor, então, indo ao encontro do máximo de liberdade, do máximo de improvisação, o mais próximo possível do jogo. O balançar da aula se baseia na esperança de que algo aconteça, algo que responda de alguma maneira àquilo que foi preparado e que, no entanto, não havia sido previsto, escapando do seu programa. ${ }^{24}$ Esse é o desafio da sala de aula: como ser ao mesmo tempo essas duas coisas, tornando produtivo o encontro entre elas.

Mas esta aula já começou: "Sim, claro, se amanhã fizer bom tempo", ela repete, para perguntar: o que pensariam se alguém entrasse aqui e, para começar a aula, dissesse isso? Ou se alguém dissesse, simplesmente, "sim"? Que sentido poderia ter uma aula, ou uma fala qualquer, que começasse com um sim? Estaríamos à beira da incoerência, aparentemente, porque o sim pressupõe um antes, e é dependente da existência de algo anterior a ele. $O$ sentido que ele pode ter é inteiramente dependente daquilo que já foi. O sim é uma cena narrativa mínima, é a resposta a um chamado.

O sim sinaliza a existência de um outro, precedente e precursor. Assim, mesmo aqui, hoje, nesta primeira aula de seu primeiro semestre, seria preciso lembrar que houve um antes, algo anterior a esta aula - para as alunas, para os alunos, para a professora, para as carteiras, para essas paredes. Haverá então na aula necessariamente algo de retomada, talvez até de repetição; há, ao menos, a repetição desta cena básica de que participamos - a cena escolar - e neste caso também a repetição de outro início, aquele que abriu o To the Lighthouse de Virginia Woolf: " 'Yes, of course, if it's fine tomorrow,' said Mrs. Ramsay”. Mas mesmo lá, no que é o começo do romance, a senhora Ramsay já está respondendo - ao filho, que desejava ir de barco ao farol. Para ele, as palavras ditas pela mãe, em resposta a uma pergunta sua que não ouvimos, 
passavam uma alegria extraordinária, como se a questão estivesse resolvida, a expedição estivesse destinada a se realizar, e a maravilha pela qual tinha ansiado por anos a fio parecesse estar, após a escuridão de uma noite e o velejar de um dia, ao alcance da mão. Como ele pertencia, mesmo com seis anos, àquele imenso clã que não consegue manter este sentimento separado daquele, mas deve deixar as possibilidades futuras, com suas alegrias e tristezas, nublar o que está realmente à mão, como para essas pessoas, mesmo na mais tenra infância, qualquer giro na roda da sensação tem o poder de cristalizar e transfixar o momento sobre o qual ela lança sua obscuridade ou sua radiância, James Ramsay, sentado no chão, recortando gravuras do catálogo ilustrado das Lojas do Exército e da Marinha, conferia à gravura de um refrigerador, enquanto a mãe falava, um gozo celestial. Ela estava envolta em prazer. O carrinho de mão, o aparador de grama, o som dos álamos, as folhas empalidecendo antes da chuva, as gralhas grasnando, as vassouras batendo, os vestidos farfalhando - todas essas coisas eram tão coloridas e distintas em sua mente que ele já tinha o seu código pessoal, a sua linguagem secreta, embora aparentasse a imagem de absoluta e intransigente severidade, com sua fronte elevada e seus penetrantes olhos azuis, impecavelmente cândidos e puros, franzindo levemente os cenhos à vista da fragilidade humana, de maneira que a mãe, observando-o manejar habilmente a tesoura em volta do refrigerador, imaginou-o todo em arminho e rubro no tribunal ou administrando um caso espinhoso e decisivo nalguma crise dos negócios públicos. ${ }^{25}$

O sim da senhora Ramsay é entendido pelo filho como uma promessa, cuja enunciação é suficiente para gerar alegria e expectativa diante das possibilidades futuras (que não são, como se verá, as mesmas imaginadas pela mãe). $O$ começo do romance será a negociação entre o sim da mãe e o não do pai, pois é assim que continua a narrativa, com o pai interrompendo a cena e imediatamente lançando uma sombra sobre seu brilho e sua cor: "'Mas', diz o pai, parando em frente da janela da sala de estar, 'não fará bom tempo."

Assim como o não, o sim é sempre uma resposta - ela continua, levantando os olhos do livro que tem nas mãos -, como nesta aula também há uma tentativa de resposta. (Foi a necessidade de elaborar melhores repostas a perguntas feitas em sala de aula que me levou ao feminismo, por exemplo.) Aqui também a resposta é ao mesmo tempo a mais de um: a Virginia Woolf; a Joyce, que termina o Ulysses (que já trazia o yes cifrado e anunciado desde o título) com uma sequência de sins:

[25] Woolf, V. Ao farol. Tradução de T. Tadeu. São Paulo: Autêntica Editora, 2013, p.5-6. 
[26] Joyce, J. Ulysses. Oxford: Oxford University Press, 2008. Na tradução de Caetano W. Galindo, lê-se: “...e aí pedi com os olhos pra ele pedir de novo sim e aí ele me perguntou se eu sim diria sim minha flor da montanha e primeiro eu passei os braços em volta dele sim e puxei ele pra baixo pra perto de mim pra ele poder sentir os meus peitos só perfume sim e o coração dele batia que nem louco e sim eu disse sim eu quero Sim." Em Joyce, J. Ulysses. São Paulo: Penguin Companhia, 2012. Há outras respostas, menos evidentes, embutidas nessas, como a resposta a Derrida (o Derrida de "Ulysses Gramophone: Hear Say Yes in Joyce". Tradução de F. Raffoul. In: A. Mitchell e S. SLote, orgs. Derrida and Joyce. N. York: SUNY Press, 2013) e a resposta a Anca Parvulescu (em "To Yes-Laugh: Derrida's Molly." Parallax, 16, iii, n. 56, julho-setembro 2010: 16-27). Ambos responderam aos yeses de Joyce, chegando a contá-los, sistematizá-los, categorizá-los, definindo-os como o sim mais famoso da literatura ocidental. ....and then I asked him with my eyes to ask again yes and then he asked me would I yes to say yes my mountain flower and first I put my arms around him yes and drew him down to me so he could feel my breasts all perfume yes and his heart was going like mad and yes I said yes I will Yes. ${ }^{26}$

Esses sins - o do romance de Woolf, o do começo desta aula - seriam um modelo perfeito de um começo in medias res, não fosse a complexidade estonteante, vertiginosa, do simples conceito de começo. Quando se pode dizer que algo começa, que está começando? O que é previamente necessário para que um momento seja identificado justamente como um começo? O que houve antes do começo? Antes que se começasse, o que acontecia? Quando, afinal, seria possível declarar que não estamos no meio das coisas?

Ao mesmo tempo em que responde a um antecedente, o gesto da aula, o gesto da escrita, está sempre em busca de uma resposta, com o movimento oscilando não apenas entre o sim e o não, em suas diferentes formas e sentidos, mas também entre o sim (a possibilidade do porvir, a chance de que algo escape, apesar de tudo) e o fim. Como seria uma aula que terminasse não no fim, mas com um sim? Uma prática pedagógica, uma prática de escrita, que evitasse o encerramento, que apontasse para as brechas presentes no pensamento, na política, que sinalizasse tudo aquilo que ainda está por ser feito? Um aluno lhe diz, um dia, que toda aula sua parece concluir da mesma maneira, com as palavras "Ainda não terminamos". Claro, é isso, a aula não quer acabar; o sim que ela (a aula, a professora) busca seria uma contra-assinatura, uma resposta que seja uma promessa de continuidade e a manifestação da vontade de continuar a pensar junto. Se tudo então se trata da busca de formas de adiar o fim, de evitar que o círculo se feche definitivamente, isso quer dizer que não pode mesmo haver outro final para a aula a não ser este: Continuamos na próxima aula? I
MARCOS NATALI - Professor de Teoria Literária e Literatura Comparada na Universidade de São Paulo. 
